\title{
Professional Qualification of Teachers Influences on Management of Teaching and Fostering Self-directed Learning for Students at District 10, Ho Chi Minh City
}

\author{
Truong Phan Nguyen Dong (Corresponding author) \\ University of Social Science and Humanities Vietnam National Univeristy \\ 10-12 Dinh Tien Hoang St. Dist. 1, Ho Chi Minh City \\ Tel: 84-0937-960-567Ｅ-mail: truongphannguyen.ebkmf@gmail.com
}

Received: August 14, 2021

doi: 10.5296/ire.v9i2.18941
Accepted: September 1, $2021 \quad$ Published: September 5, 2021

URL: https://doi.org/10.5296/ire.v9i2.18941

\begin{abstract}
The research was aimed to investigate on what level of teachers' professional qualifications influenced the management of teaching and fostering self-directed learning for students in the primary schools in District 10, Ho Chi Minh City, Vietnam. According to Watson (2001), with the total population ranging from 700 to 800 people, with a confidence level of $50 \%$, the appropriate sample size ranges from 255 to 267 people. The total number of primary school teachers in District 10, Ho Chi Minh City was 769 people, thus, the survey sample in this study was 265 people, according to Watson (2001), this sample is appropriate. The survey sample includes 265 primary school teachers, of which 94 male teachers $(35.5 \%)$ and 171 female teachers $(64.5 \%)$. The result revealed that the professional qualification of teachers influences significantly on management of teaching and fostering self-directed learning for students at District 10, Ho Chi Minh City.
\end{abstract}

Keywords: Professional qualification, Management of teaching and fostering self-directed learning, Primary students

\section{Introduction}

The new education program promulgated by the Vietnamese Ministry of Education and Training in 2018 has built a new orientation in education and training and educational management in Vietnam. Vietnamese education focuses on developing students' competencies, including self-directed learning. This orientation is one of the correct and potential directions for educational developments in the world. However, teacher training has 
not been reformed, as evidenced by the fact that although the teaching is implemented in a new direction, the assessment of the quality of pedagogical students and teachers is still in the traditional way. This research aims to investigate how the professional qualifications of teachers have an impact on the management of teaching and fostering self-directed learning for students in the primary schools in District 10, Ho Chi Minh City.

\subsection{Management Concept}

Management is a field studied by many Vietnamese and foreign scholars and it has a long history of research. However, within the scope of research and investigation of the topic, the study would like to give the researchers' approach to management views and synthesize from there, it is proposed that the management perspective is used as a theory basis in this study. Based on theories and practices of management, researchers have given their views on management as a purposeful effect (Pham Minh Hac, 1986; Nguyen Quoc Chi \& Nguyen Thi My Loc, 1997; Nguyen Ngoc Quang, 1997; Nguyen Minh Dao, 1997) of the management subject to the management object to achieve the common goals of the organization. Besides, the researchers also added other points of view. According to H. Koontz (1992), he believed that management was an essential activity, it ensured the coordination of efforts of individuals to achieve organizational goals. The aim of every manager is to create an environment in which people can achieve their goals with the least amount of time, money, material, and personal dissatisfaction. Group of researchers including Nguyen Quoc Chi and Nguyen Thi My Loc (1997) said that: "Management activity is the directional and intentional impact of the management subject (manager) on the managed object (person managed) within an organization to enable it to function and achieve its goals". According to Dang Quoc Bao (2008), management is two parallel activities, coordinating and mobilizing to help the organization adapt and operate effectively in an interactive environment between the organization and external factors, between the organization and the organization's functions and internal factors. In this study, the author believed that management is an activity that always has two components, the subject of management and the object of management. The management subject can be an individual or a group of people who have the function of planning, organizing, pointing, and controlling so that the organization can operate effectively and achieve its goals. Management objects are those who are under the influence of the managed subject to achieve common goals.

\subsection{Self-directed Learning of Primary Schoolers}

Self-directed learning is one of the topics attracting many Vietnamese scholars interested in research. Within the limits of our research, we have found some definitions of the self-directed learning of Vietnamese researchers. In which, Nguyen Canh Toan (1997, 2002) was the first to give a full perspective on self-directed learning in Vietnam. He believed that self-directed learning is brainstorming by yourself, using your own intellectual abilities (such as monitoring, comparing, analyzing, synthesizing, ...) and sometimes even muscle capacity (such as when to use tools, means, ...) along with their personal qualities such as motivation, affection, life view, worldview (such as honesty, objectivity, progress, ...) to dominate a certain field of human knowledge and make it his property. This view has been agreed and 
cited by many Vietnamese researchers such as: Nguyen Thi Lan Huong (2009); Duong Van Phuong (2011); Lam Thi Bach Tuyet (2013); Le Van Hai (2014). In addition, some other scholars also added their views on self-directed learning such as: self-directed learning is often understood as learning with books, without a teacher by your side (Le Thi Thu Hien, 2017); self-directed learning is an individual cognitive activity (Tran Thi Dung, 2012); self-directed learning can be carried out outside the classroom and has a strong personal identity (Dang Vu Hoat, Ha Thi Duc, 2013); self-directed learning comes from the need and desire to occupy learners' knowledge (Le Trong Duong, 2006); self-directed learning is the ability to perceive and apply knowledge to new situations (Dang Thanh Hung, 2000; Le Cong Triem, 2001).

Thus, from 1975 until now, Vietnamese scholars have inherited and made comments and added to the theory of self-directed learning quite fully and completely. When it comes to self-directed learning, scholars commented about individual needs, autonomy, cognitive autonomy, and individual responsibility in learning. Self-directed learning can take place in any space with different situations. Self-directed learning is applying knowledge to new situations. Besides, in Circular 32/2018/TT-BGDĐT promulgating the new general education program, Hanoi, December 26, 2018, the Ministry of Education of Vietnam has a clear definition of self-directed learning in elementary school students. Students with self-directed learning consciously summarizing and presenting what they have learned. Students with self-directed learning can recognize and correct errors in the test through the teacher's comments. Students with self-directed learning consciously learn from teachers, friends, and others to consolidate and expand their understanding. Students have a sense of learning and follow good examples. Within the scope of this research, we use the definition of self-directed learning from the point of view of the Ministry of Education and Training, Vietnam. Thus, in this study, we follow the view of the Ministry of Education and Training on the concept of self-directed learning of primary school students.

\subsection{Teaching and Fostering Self-directed Learning for Primary Schoolers}

Teaching and fostering competency for students is one of the topics in recent years attracting many scholars and researchers in Vietnam according to new direction in Vietnamese Education program. Teaching and fostering competency for students have been given many different definitions by researchers. According to Nguyen Cat Tuong Anh (2019), the author believed that teaching and fostering competency for students in the process of organizing and implementing activities of teachers and students based on educational programs towards the formation and development of competency for students such as developing self-control and self-study, communication and cooperation, problem-solving through activities to form students' competencies such as language, computation, natural and social inquiry, technology, informatics, aesthetic, physical and gifted students. According to Le Dinh Trung and Phan Thi Thanh Hoi (2020), teaching and fostering competency is teaching-oriented to develop learners' capacity, which is a teaching activity that expands content-oriented by creating an environment, context, and teaching specific context for students to perform activities to apply knowledge, use skills, and express their attitudes. Within the scope of the topic and research, research applied the concept of teaching and fostering competency of Le Dinh Trung and 
Phan Thi Thanh Hoi (2020).

From the theory of teaching and fostering competency and self-directed learning of primary school students, self-directed learning training and fostering activities for primary school students are understood as content-oriented teaching activities, methods. The method of teaching aims to create a specific environment and context for students to consciously summarize, present what they have learned, and be able to recognize and correct errors in the examination through the teacher's comments. Students with self-directed learning has a sense of learning from teachers, friends, and others to strengthen and expand her understanding and a sense of learning and following good examples. In the view of Le Dinh Trung and Phan Thi Thanh Hoi (2020), the content of self-directed learning training and fostering activities for primary school students includes elements of teaching activities, such as teaching objectives, teaching content, teaching method, and testing methods and teaching equipment.

\subsection{Management of Teaching and Fostering Self-Directed Learning for Students' Primary School}

On the theoretical basis presented, the management of teaching activities to develop self-study ability for primary school students is understood as the purposeful impact of the management subject on teaching and learning activities. Self-study capacity for primary school students by teachers through the implementation of management functions in determining objectives, content, methods, teaching organization and assessment forms, together with the use of teaching media and organization of learning activities for students. The purpose of the management of teaching activities to develop self-study ability for elementary students is to help students consciously summarize and present what they have learned, be able to recognize and correct mistakes. to fail the test through the teacher's comments, to consciously learn from teachers, friends and others to strengthen and expand understanding, and to have a sense of learning and following good examples. The purpose of the management of teaching activities to develop self-study ability for elementary students is to help students consciously summarize and present what they have learned, be able to recognize and correct mistakes. to fail the test through the teacher's comments, to consciously learn from teachers, friends and others to strengthen and expand understanding, and to have a sense of learning and following good examples.

On the basis of the theory of management activities and management of teaching activities to develop self-study ability for primary school students, the content of teaching management activities to develop self-study ability for elementary students is determined. The decision includes the following issues: Management of teaching activities to develop self-study capacity (including: management of teaching objectives to develop self-study capacity, management of teaching content to develop self-study capacity, management of manage teaching forms to develop self-study capacity, manage teaching methods to develop self-study capacity, manage testing and evaluation activities); Managing students' learning activities in order to develop self-study ability; Managing teaching means to develop students' self-study ability.

1.5 Professional Qualification of Teachers Influences on Management for Teaching and 
Fostering Self-Directed Learning for Students at District 10, Ho Chi Minh City

In human resource management, Hays and Kearney (2001) argued that the development and training of human resources is the main factor in constituting the effectiveness of the organization. Hays and Kearney (2001) one of the main approaches to human resource development and training is to recruit and develop excellent employees. According to the Mason (1999) and Peterson (1999), excellent employees will be confident in their work, loyal to the work and the organization, thereby increasing work efficiency and favorable for management. According to Seweje and Jegede (2005), teachers' qualifications are not only reflected in their professional knowledge but also in pedagogical skills. According to Ngada in Fajonyomi (2007), the success of an educational program depends largely on the qualifications, competence, and dedication of the teachers. Thus, the factor of professional qualifications of staff or teachers in an educational organization has a great influence on the effectiveness of the organization as well as on the management activities of that educational institution.

According to Clause b, Article 72 of the Vietnam Education Law 2019 stipulates the standard training qualifications of teachers as follows: "Having a bachelor's degree in the field of teacher training or higher, for teachers of primary, middle, and high schools, Common. If the subject is not enough, the teacher must have a bachelor's degree in the field of teacher training, a bachelor's degree in a relevant discipline and a certificate of pedagogical training.". Based on the Vietnam Education Law (2019) on the qualifications of primary school teachers, within the scope of the research topic, convenient for the survey, we propose a Likert scale, 5 levels, the levels gradually increase with 1 is "strongly disagree" and 5 is "strongly agree". The scale has 3 items as follows: The teachers at the Primary School are highly qualified; The teachers at the Primary School have good knowledge and skills in self-leadership and good teaching management; The teaching staff at the Primary School you are working with have practical experience in teaching activities to develop competence, specifically self-directed learning for students.

\section{Method}

\subsection{Participant (Subject) Characteristics}

According to Watson (2001), with the total population varying from 700 to 800 people, with a confidence level of 50\%, the appropriate sample size ranges from 255 to 267 people. The total number of primary school teachers in District 10, Ho Chi Minh City is 769 people, so, the survey sample in this thesis is 265 people, according to the formula of Watson (2001) is appropriate. The survey sample includes 265 primary school teachers, of which 94 male teachers $(35.5 \%)$ and 171 female teachers $(64.5 \%)$. By seniority, there were 74 primary school teachers with less than 5 years of experience (accounting for 27.9\%); there were 79 primary school teachers with 6 to 10 years of working experience (accounting for 29.8\%); There were 55 primary school teachers with 11 to 15 years of experience (accounting for $20.8 \%$ ); There were 36 primary school teachers with 16 to 20 years of experience (accounting for $13.6 \%$ ); There were 21 primary school teachers with more than 20 years of experience (accounting for $7.9 \%$ ). 


\subsection{Research Design}

The main research method in this study was the questionnaire survey method. Based on the theoretical basis, the researchers built a questionnaire with contents about the actual situation of self-directed learning training activities. The author used a 5-level Likert or nominal scale with the number of observed variables depending on the content of the question group. The author used a 5-level Likert scale and divides the levels according to the following formula: the values of the items, level $=(5-1) / 5=0.8$ (followed by Duong Minh Quang et al., 2018). Therefore, the significance of the levels is divided as follows: Average score from 1.00 to 1.80: completely dissatisfied / completely disagree / completely unimportant; Average score from 1.81 to 2.60: not satisfied/disagree/not important; Average score from 2.61 to 3.40: partly satisfied / partly agree / partly important; Average score from 3.41 to 4.20: satisfied/agree/important; Average score from 4.21 to 5.00: completely satisfied/strongly agree/strongly important.

After having the content of the questionnaire, the study invited 35 teachers from primary schools voluntarily test the questionnaire (these teachers will not be invited to participate in the official survey). The purpose of the pilot survey was for the teachers to give feedback on the language used and to check if the teachers' time is appropriate so that appropriate adjustments can be made before conducting a formal investigation. The reliability and validity of the scale were tested using Cronbach's Alpha reliability coefficient method and exploratory factor analysis (EFA) through SPSS 20.0 processing software to screen, remove observed variables that do not meet the reliability criteria.

\section{Results}

\subsection{Cronbach's Alpha Analysis and Exploratory Factor Analysis (EFA)}

The results of evaluating reliability of Cronbach's alpha and the factor analysis of the scale of management of teaching and fostering self-directed learning for primary students at District 10, Ho Chi Minh City presented in Table 01. The test results show that the scale has full reliability (Cronbach's alpha coefficient varies from 0.898 to 0.937 with the scale of teaching and learning management activities to develop self-study capacity and Cronbach's alpha coefficient varies from 0.61 to 0.80 ). The scale of management of teaching and learning activities to develop self-study ability extracted 7 factors with factor loading coefficient varying from 0.503 to 0.862 (KMO index reached 0.921 ). The leadership style scale extracted 6 factors with the factor loading coefficient varying from 0.749 to 0.887 (KMO index reached $0.8399)$. 


\section{Mll Macrothink}

International Research in Education

ISSN 2327-5499

2021, Vol. 9, No. 2

Table 1. Cronbach's alpha and EFA results of scale of management of teaching and fostering self-directed learning for primary students at District 10, Ho Chi Minh City

\begin{tabular}{|c|c|c|c|c|c|c|}
\hline \multirow[b]{2}{*}{ Scale } & \multirow[b]{2}{*}{ Items } & \multicolumn{2}{|c|}{ Cronbach's Alpha } & \multicolumn{2}{|l|}{ EFA } & \multirow[b]{2}{*}{ Factor loading } \\
\hline & & $\begin{array}{l}\text { Cronbach' } \\
\text { S Alpha } \\
\text { index }\end{array}$ & $\begin{array}{l}\text { Total } \\
\text { correlation }\end{array}$ & $\begin{array}{l}\mathrm{KMO} \\
\text { index }\end{array}$ & $\begin{array}{l}\text { Cumula } \\
\text { tive }(\%)\end{array}$ & \\
\hline \multicolumn{2}{|c|}{$\begin{array}{l}\text { Scale of management of } \\
\text { self-directed learning for prima } \\
\text { Ho Chi Minh City (38 items) }\end{array}$} & $\begin{array}{l}\text { ching and } \\
\text { students at }\end{array}$ & $\begin{array}{l}\text { fostering } \\
\text { District } 10\end{array}$ & \multirow{8}{*}{0.921} & \multirow{8}{*}{74.265} & \multirow{8}{*}{$\begin{array}{l}7 \text { factors với } \\
\text { factor loading } \\
\text { varying from } \\
0.503-0.862\end{array}$} \\
\hline $\begin{array}{l}\text { Manageing teaching } \\
\text { goals }\end{array}$ & 5 & 0.915 & $\begin{array}{l}0.77 \\
0.80\end{array}$ & & & \\
\hline $\begin{array}{l}\text { Manageing teaching } \\
\text { content }\end{array}$ & 5 & 0.909 & $\begin{array}{l}0.76 \\
0.80\end{array}$ & & & \\
\hline $\begin{array}{l}\text { Managing teaching } \\
\text { methods }\end{array}$ & 5 & 0.898 & $\begin{array}{l}0.73 \\
0.80\end{array}$ & & & \\
\hline $\begin{array}{l}\text { Managing organization } \\
\text { of teaching activities }\end{array}$ & 5 & 0.905 & $\begin{array}{l}0.72 \\
0.79\end{array}$ & & & \\
\hline $\begin{array}{l}\text { Manageing evaluation } \\
\text { activities }\end{array}$ & 5 & 0.904 & $\begin{array}{l}0.72 \\
0.80\end{array}$ & & & \\
\hline $\begin{array}{l}\text { Manageing learning } \\
\text { activities of learners }\end{array}$ & 8 & 0.931 & $\begin{array}{l}0.68 \\
0.85\end{array}$ & & & \\
\hline $\begin{array}{l}\text { Manageing } \\
\text { equipment }\end{array}$ & 5 & 0.937 & $\begin{array}{l}0.73 \\
0.86\end{array}$ & & & \\
\hline $\begin{array}{l}\text { Scale of Professional } \\
\text { qualification } \\
\text { teachers }\end{array}$ & 3 & 0.708 & $\begin{array}{l}0.48 \\
0.58\end{array}$ & 0.662 & 63.274 & $\begin{array}{l}1 \text { factors }- \text { factor } \\
\text { loading from } \\
0.567-0.693\end{array}$ \\
\hline
\end{tabular}

3.2 Management of Teaching and Fostering Self-Directed Learning for Primary Students at District 10, Ho Chi Minh City, Vietnam

According to the research results, the management in evaluating and examining teachers' teaching and fostering self-directed learning for primary students was considered by primary school teachers to be the most effective section (mean score $=4.29$, standard deviation $=$ 0.54). In addition, the research results also showed that the management of learning activities and the management of teaching equipment applied technology are highly effective by primary school teachers (mean score $=4.20 ; 4.21$; standard deviation $=0.59,0.63$, respectively). The management of building teaching goals was evaluated to be less effective than other management activities (mean score $=4.07$; standard deviation $=0.72$ ). Independent $\mathrm{T}$ - Test tests the difference in the evaluation of the effectiveness of the 
management amongst teachers. The results of the Independent T-test indicated that the teachers were quite similar in terms of evaluating the effectiveness of the management content, but in evaluating management of teaching equipment, there was a significant difference. Statistical significance between male teachers and female teachers when in term of evaluating effectiveness of management teaching equipment. Specifically, male teachers rated the management of teaching equipment was higher than female teachers' evaluations (average score of $4.34>4.13$ ).

Table 2. Management of teaching and fostering self-directed learning for primary students at District 10, Ho Chi Minh City, Vietnam

\begin{tabular}{|c|c|c|c|c|}
\hline Management of teaching and & Male & Female & Sum & \\
\hline $\begin{array}{l}\text { fostering self-directed learning for } \\
\text { primary students at District } 10 \text {, Ho } \\
\text { Chi Minh City, Vietnam }\end{array}$ & $\begin{array}{l}\text { Mean } \\
\text { (Std.D) }\end{array}$ & $\begin{array}{l}\text { Mean } \\
\text { (Std.D) }\end{array}$ & $\begin{array}{l}\text { Mean } \\
\text { (Std.D) }\end{array}$ & $\mathbf{F}$ \\
\hline Manageing teaching goals & $3.99(0.86)$ & $4.12(0.63)$ & $\begin{array}{l}4.07 \\
(0.72)\end{array}$ & -1.337 \\
\hline Manageing teaching content & $4.11(071)$ & $4.18(0.66)$ & $4.15(0.68)$ & -0.791 \\
\hline Managing teaching methods & $4.10(0.74)$ & $4.10(0.66)$ & $4.10(0.69)$ & -0.07 \\
\hline $\begin{array}{l}\text { Managing organization of teaching } \\
\text { activities }\end{array}$ & $4.05(0.71)$ & $4.16(0.65)$ & $\begin{array}{l}4.13 \\
(0.68)\end{array}$ & 0.200 \\
\hline Manageing evaluation activities & $4.30(0.59)$ & $4.28(0.52)$ & $4.29(0.54)$ & 0.215 \\
\hline Manageing learning activities of learners & $4.28(0.62)$ & $4.16(0.57)$ & $4.20(0.59)$ & 1.689 \\
\hline Manageing teaching equipment & $4.34(0.60)$ & $4.13(0.64)$ & $4.21(0.63)$ & $2.503 * * *$ \\
\hline
\end{tabular}

Note: ** when $p<0.01$

\subsection{Professional Qualification of Teachers in Primary School at District 10, Ho Chi Minh City}

The professional qualification of teachers in primary schools at District 10, Ho Chi Minh City, Vietnam was agreed that it was good and well-trained by teachers of primary schools in District 10, Ho Chi Minh City when they are evaluated their peers (Mean =3.78; Std. $\mathrm{D}=0.806$ ). All of the teachers in District 10, Ho Chi Minh City in evaluating their peers agreed that the teachers at primary school in District 10 were highly qualified and attained good teaching management. (mean=3.9;3.8 respectively and $\mathrm{Std} . \mathrm{D}=1.02 ; 0.99$ respectively). The independent T-test was administrated to examine the differences between male and female teachers in rating their peers' professional qualification. The result revealed that there were no differences between male and female teachers in evaluating professional qualification of teachers in District 10, Ho Chi Minh City. 
Table 3. The professional qualification of teachers in primary schools at District 10, Ho Chi Minh City, Vietnam

\begin{tabular}{|c|c|c|c|c|}
\hline \multirow{2}{*}{$\begin{array}{l}\text { Professional qualification of teachers in } \\
\text { primary school at District 10, Ho Chi Minh } \\
\text { City }\end{array}$} & Male & Female & Sum & \multirow[b]{2}{*}{$\mathbf{F}$} \\
\hline & $\begin{array}{l}\text { Mean } \\
(\text { Std.D) }\end{array}$ & $\begin{array}{l}\text { Mean } \\
(\text { Std.D) }\end{array}$ & $\begin{array}{l}\text { Mean } \\
\text { (Std.D) }\end{array}$ & \\
\hline $\begin{array}{l}\text { The teachers at the Primary School are highly } \\
\text { qualified }\end{array}$ & $3.9(1.08)$ & $3.9(0.98)$ & $3.9(1.02)$ & 1.774 \\
\hline $\begin{array}{l}\text { The teachers at the Primary School have good } \\
\text { knowledge and skills in self-leadership and } \\
\text { good teaching management }\end{array}$ & $\begin{array}{l}3.83 \\
(1.08)\end{array}$ & $\begin{array}{l}3.83 \\
(0.93)\end{array}$ & $3.8(0.99)$ & 1.980 \\
\hline $\begin{array}{l}\text { The teaching staff at the Primary School you } \\
\text { are working with have practical experience in } \\
\text { teaching activities to develop competence, } \\
\text { specifically self-directed learning for students. }\end{array}$ & $3.60(1.0)$ & $\begin{array}{l}3.60 \\
(1.05)\end{array}$ & $3.6(1.03)$ & 0.366 \\
\hline $\begin{array}{l}\text { Professional qualification of teachers in } \\
\text { primary school at District 10, Ho Chi Minh } \\
\text { City }\end{array}$ & $\begin{array}{l}3.78 \\
(0.84)\end{array}$ & $\begin{array}{l}3.78 \\
(0.78)\end{array}$ & $\begin{array}{l}3.78 \\
(0.806)\end{array}$ & 0.089 \\
\hline
\end{tabular}

3.4 Professional Qualification of Teachers Influences on Management for Teaching and Fostering Self-Directed Learning for Students at District 10, Ho Chi Minh City

The Pearson test was administrated to the research to examine the correlation between professional qualification of teachers and management of teaching and fostering self-directed learning for primary students at District 10, Ho Chi Minh City. The result revealed that professional qualification of teachers has strong positive correlation with management of teaching and fostering self-directed learning for primary students at District 10, Ho Chi Minh City (Pearson index $=0.441$; significant level $<0.01$ ). Besides that, professional qualification of teachers is found the be strongly positively correlated with managing learning activities of learners and managing teaching equipment (Pearson index $=0.365 ; 0.345$ respectively with significant level $<0.01)$. The weakest correlation was between managing teaching goals and management of teaching and fostering self-directed learning for primary students at District 10, Ho Chi Minh City (Pearson index=0.244; significant level<0.01). 
Table 4. Correlation and regression between professional qualification of teachers and management of teaching and fostering self-directed learning for primary students at District 10, Ho Chi Minh City

\begin{tabular}{|c|c|c|}
\hline \multirow[b]{2}{*}{ Dependent variables } & \multicolumn{2}{|c|}{$\begin{array}{l}\text { Impact variables (Professional } \\
\text { qualification of teachers) }\end{array}$} \\
\hline & $\begin{array}{l}\text { Correlation } \\
\text { index }\end{array}$ & $\begin{array}{l}\text { Regression index } \\
r^{2}\end{array}$ \\
\hline Manageing teaching goals & $0.244 * *$ & $0.056^{* * *}$ \\
\hline Manageing teaching content & $0.327 * *$ & $0.104 * * *$ \\
\hline Managing teaching methods & $0.341 * *$ & $0.113 * * *$ \\
\hline Managing organization of teaching activities & $0.293 * *$ & $0.082 * * *$ \\
\hline Manageing evaluation activities & $0.350 * *$ & $0.119 * * *$ \\
\hline Manageing learning activities of learners & $0.365 * *$ & $0.130 * * *$ \\
\hline Manageing teaching equipment & $0.345^{* *}$ & $0.116^{* * *}$ \\
\hline $\begin{array}{l}\text { Management of teaching and fostering } \\
\text { self-directed learning for primary students at } \\
\text { District 10, Ho Chi Minh City }\end{array}$ & $0.441 * *$ & $0.192 * * *$ \\
\hline
\end{tabular}

Note: $* *$ when $\mathrm{p}<0.01 ; * * *$ when $\mathrm{p}<0.001$.

Besides that, the researchers also conducted single regression for analysis the level of impacts of professional qualification of teachers on management of teaching and fostering self-directed learning for primary students at District 10, Ho Chi Minh City. The result showed that overall, the professional qualification of teachers accounted for $19,2 \%$ changes in management of teaching and fostering self-directed learning for primary students at District 10, Ho Chi Minh City. On the other hands, professional qualification of teachers impacts significantly on managing learning activities of learners (accounted for $13 \%$ changes in managing learning activities of learners). The weakest impacts of professional qualification were on managing teaching goals (accounted only for $0.56 \%$ changes in this section).

\section{Discussion and Conclusion}

The research revealed that professional qualification of teachers influenced significantly on several aspects of management for teaching and fostering self-directed learning for students at District 10, Ho Chi Minh City. The management for teaching and fostering self-directed learning for students at District 10, Ho Chi Minh City was rated as effective by teachers and there are no differences between male and female teachers. It showed that the management of principals of primary school in District 10 was effective and well-controlled. The study also indicated that professional qualification of teachers was highly trained and qualified with good teaching management skill. The professional qualification of teachers correlated 
positively and strongly with management for teaching and fostering self-directed learning for students at District 10, Ho Chi Minh City, especially in managing learning activities of learners and managing teaching equipment. From this result, the education management in District 10, Ho Chi Minh City should focus more on improve and fostering teachers' qualification in order to match with new direction in education of Vietnam, fostering and developing competencies for students.

\section{References}

Bộ Giáo dục và Đào tạo. (2018). Chuoong trình giáo dục phổ thông. Thông tu số 32/2018/TT-BGDĐT, ngày 26/12/2018.

Dussault, M., Frenette, É., \& Fernet, C. (2013). Leadership: Validation of a Self-Report Scale. Psychological Reports, 112(2), 419-436. https://doi.org/10.2466/01.08.PR0.112.2.419-436

Dương Minh Quang, Nguyễn Thị Hảo, \& Nguyễn Hồng Phan (2018), Hiệu quả giảng dạy của giảng viên lý luận và thực tiễn, Nhà xuất bản Đại học Quốc Gia Thành phố Hồ Chí Minh. Dương Văn Phương (2011). Luận văn Thạc sỹ Quản lý Một Số Giải Pháp Quản Lý Hoạt Động Tự Học Của Học Sinh Truờng Trung Học Phổ Thông Dân Tộc Nội Trú Tỉnh Thanh Hoá.Trường Đại học Vinh.

Đặng Quốc Bảo. (2008). Tổng quan về Tổ chức và Quản lý, tài liệu dành cho các lớp Cao học Quản lý Giáo dục, 2008.

Đặng Thành Hưng (lược dịch). (2000). Một số vấn đề về phuoong pháp dạy học, Viện Khoa học Giáo dục, Hà Nội.

Đặng Vũ Hoạt (chủ biên), Hà Thị Đức. (2013). Li luận dạy học đại học, Nxb Đại học Sư phạm, Hà Nội.

Đỗ Thị Thùy (2019). Thực trạng và biện pháp ứng dụng công nghệ thông tin trong dạy học ở các trường Tiểu Học Quận Gò Vấp, Thành Phố Hồ Chí Minh, Tạp chí Giáo dục, Số đặc biệt tháng 7/2019, tr 21-24; 20

Engen, M. L., Leeden, R., \& Willemsen, T. M. (2001), Gender, context and leadership styles: A field study, Journal of Occupational and Organizational Psychology, 74(5), 581-598. https://doi.org/10.1348/096317901167532

Fajonyomi, A. A. (2007). Reviving higher education relevance in Nigeria. A paper presented at the 3rd Faculty of Week and Annual National Conference, Faculty of Education. University of Maiduguri on the theme Higher education reforms in Nigeria from 26th to 27th September

Guskin, A. E., \& Bassis, M. A. (1985). Leadership styles and institutional renewal, New Directions for Higher Education, 1985(49), 13-22. https://doi.org/10.1002/he.36919854904

Hà Thị Dung. (2013). Quản Lý Hoạt Động Tụ Học Của Học Sinh Truờng Trung Học Co Sở Mông Ân Huyện Bình Gia - Lạng Sơn, Luận văn Thạc Sĩ với đề tài thuộc Đại Học Quốc Gia Hà Nội Trường Đại Học Giáo Dục.

Harold, Koontz, Cyrill O,donnell. \& Heninz Weihrich. (1992). Nhũ̃ng vấn đề cốt yếu của quản lý. Nhà xuất bản Khoa học Kỹ thuật, Hà Nội. 


\section{Mll Macrothink}

International Research in Education

ISSN 2327-5499

2021, Vol. 9, No. 2

Hays, S. W., \& Kearney, R. C. (2001). Anticipated changes in human resource management: Views from the field. Public Administration Review, 61(5), 585-596. https://doi.org/10. 1111/0033-3352.00129

Hoàng Đức Trí (2019). Một số biện pháp tăng cường quản lí hoạt động ứng dụng công nghệ thông tin trong dạy học ở các trường trung học cơ sở Thành Phố Đông Hà, tỉnh Quảng Trị, Tạp chí Giáo ducc, Số 444 (Kì 2 - 12/2018), tr 9-13; 8. https://doi.org/10.52714/dthu. 39.8.2019.710

Lâm Thị Bạch Tuyết. (2013). Luận văn Thạc sỹ Biện Pháp Quản Lý Hoạt Động Tự Học Của Hoc sinh Khoa Su Phạm Truò̀ng Đại Hoc Trà Vinh Trong Giai Đoạn Hiện Nay. Trường Đại học Đà Nẵng.

Lê Công Triêm. (2001). Bồi dữ̃ng năng lục tụ học, tụ nghiên cứu cho sinh viên đại học, Tạp chí giáo dục, số $8, \operatorname{tr} 30-35$.

Lê Công Triêm. (2001). Một số vấn đề hiện nay của phuơng pháp dạy học hiện đại, Nxb Đại hoc Su phạm, Hà Nội.

Lê Đình Trung, Phan Thị Thanh Hội. (2020). Dạy học theo định huoóng hình thành và phát triển năng lực người học ở truoòng Phổ Thông, Nhà xuất bản Đại học Sư Phạm, Hà Nội.

Lê Văn Hải. (2014). Luận văn Thạc sỹ Quản Lý Hoạt Động Tụ Học Của Học sinh Trường Đại Học Thủ Dầu Một, Tỉnh Bình Dương.

Mason, L. (1999). Lead the way to increased productivity. Outlook, 3, 50-55.

Nguyễn Cảnh Toàn (chủ biên), Nguyễn Kỳ, Lê Khánh Bằng, Vũ Văn Tảo (2002). Học và dạy cách học, NXB Đại học Sư phạm.

Nguyễn Cảnh Toàn (chủ biên), Nguyễn Kỳ, Vũ Văn Táo, Bùi Tường (1997), Quá trình dạy tụ học, NXB Giáo dục, Hà Nội.

Nguyễn Cát Tường Anh. (2019). Quản li hoạt động dạy học theo định hướng phát triển năng lực học sinh ở các truờng trung họ cơ sở công lập Quận Phú Nhuận Thành Phố Hồ Chí Minh, Luận văn Thạc sĩ Quản lý Giáo dục, Trường Đại học Sư Phạm Thành phố Hồ Chí Minh, 2019.

Nguyễn Minh Đạo. (1997). Cơ sở khoa học quản lý, Nhà xuất bản chính trị quốc gia Hà Nội, 1997.

Nguyễn Ngọc Quang. (1986). Lý luận dạy học đại cương. Trường Cán bộ quản lý Giáo dục.

Nguyễn Quang Thuận. (2019). Một số nguyên tắc ứng dụng công nghệ thông tin trong dạy học môn giáo dục công dân theo định hướng phát triển năng lực ở trường trung học phổ thông hiện nay, Tạp chi Giáo dục, Số 452 (Kì 2 - 4/2019), tr 61-64; bìa 3. https://doi.org/10.18173/2354-1075.2019-0008

Nguyễn Quốc Chí, Nguyễn Thị Mỹ Lộc. (1997). Nhũng co sở khoa học về quản lý giáo dục, Trường cán bộ quản lý giáo dục, 1997.

Nguyễn Thị Lan Hương. (2009). Luận văn Thac sĩ về Quản Lý Hoạt Động Tụ Học Của Học sinh Khoa Ngôn Ngũ Và Văn Hóa Nga Truờng Đại Học Ngoại Ngũ - Đại Học Quốc Gia Hà Nội Đáp Úng Yêu Cầu Đào Tạo Theo Học Chế Tín Chỉ. Trường Đại học Giáo dục.

Peterson, A. (1999). Reap the benefits of creative training solutions. Credit Union Magazine, 65(10), 29-30. 


\section{Macrothink

Phạm Minh Hạc. (1986). Một số vấn đề giáo dục và khoa học giáo dục. Nhà xuất bản Giáo dục. Hà Nội.

Quốc hội Việt Nam. (2019). Luật giáo dục, 43/2019/QH14, Hà Nội, ngày 14 tháng 06 năm 2019.

Schmid, H. (2006). Leadership styles and leadership change in human and community service organizations. Nonprofit Management and Leadership, 17(2), 179-194. https://doi.org/10.1002/nml.142

Seweje, R. O., \& Jegede, S. A. (2005). Science Education and Science Teaching Methods. Lagos: Atlantic Association.

Silins, H. C. (1992) Effective leadership for school reform. The Alberta Journal of Educational Research, 38, 317-334.

Sole, F. (2009). A management model and factors driving performance in public organizations. Measuring Business Excellence, 13(4), 3. https://doi.org/10.1108/1368304 0911006747

Trần Thị Dung. (2012). Nâng cao năng lục tụ học cho sinh viên trong giảng dạy môn nhũng nguyên lý co bản của chủ nghĩa mác - lênin (phần ii), Trường Đại học Vinh, 2012.

Watson, J. (2001). How to Determine a Sample Size: Tipsheet \#60, University Park, PA: Penn State Cooperative Extension.

\section{Copyright Disclaimer}

Copyright reserved by the authors.

This article is an open-access article distributed under the terms and conditions of the Creative Commons Attribution license (http://creativecommons.org/licenses/by/4.0/). 